\title{
Methanesulfonate in the firn of King George Island, Antarctica
}

\author{
Han Jiankang, ${ }^{1}$ Xie Zighu, ${ }^{1} Z_{\text {hang }}$ Xinping, ${ }^{1}$ Dai Dongsheng, ${ }^{2}$ P. A. Mayewski, ${ }^{3}$ M. S. Thigkler ${ }^{3}$ \\ ${ }^{1}$ Research Institute of Environment and Resources, Hunan Normal University, Changsha 410081, China \\ ${ }^{2}$ Institute of Chemistry, Chinese Academy of Sciences, Beijing 100080, China \\ ${ }^{3}$ Climate Change Research Center, Institute for the Study of Earth, Oceans and Space, University of New Hampshire, \\ Durham, New Hampshire 03824, U.S.A.
}

\begin{abstract}
Methanesulfonate was investigated as a potential contributor to the sulfur budget, based on analysis of a firn core from Collins Ice Cap, King George Island, Antarctica $\left(62^{\circ} 10^{\prime} \mathrm{S}, 58^{\circ} 50^{\prime} \mathrm{W}\right)$. The anion was found to be present at a mean concentration of $0.17 \mu \mathrm{eq} \mathrm{L} \mathrm{L}^{-1}$, with a maximum of $0.73 \mu \mathrm{eq} \mathrm{L} \mathrm{L}^{-1}$. Dating based on the $\delta^{18} \mathrm{O}$ profile suggests that the principal peaks of methanesulfonate are associated with snow deposited in summer and autumn. A careful examination of MSA, $\mathrm{SO}_{4}{ }^{2-}$ and $\mathrm{nsSSO}_{4}{ }^{2-}$ profiles indicates that two of the three peaks in the MSA profile may result mainly from migration and relocation of MSA. The mechanism responsible for this might be similar to that for deep cores from other Antarctic glaciers, supporting the migration hypothesis proposed by prior researchers and extending it to near-temperate ice. Due to the post-depositional modification, the main part of the MSA profile of the firn is no longer indicative of the seasonal pattern of MSA in the atmosphere, and the basis for calculation of the MSA/nssSO ${ }_{4}{ }^{2-}$ ratio should be changed. The $\mathrm{MSA} / \mathrm{nssSO}_{4}{ }^{2-}$ ratio obtained by a new computation is $0.22,10 \%$ higher than that ignoring the effect of MSA migration.
\end{abstract}

\section{INTRODUGTION}

It is now well recognized that the oceanic biogenic sulfur cycle plays an important role in the forcing of global climate. Dimethylsulfide (DMS) derived from the planktonic algae in sea water oxidizes in the marine atmosphere to form sulfate aerosols, serving as the major source of the cloud condensation nuclei (CCN). A rise in the CGN population may cause an increase in the albedo of marine stratus clouds, lowering the incident solar radiation, thus affecting the Earth's radiation budget. This mechanism proposed by Charlson and others (1987) includes another by-product of the DMS oxidation, methanesulfonic acid (MSA), which can be as effective as CGN in the marine atmosphere.

Unlike sulfate, which may have various sources (terrestrial, volcanic, anthropogenic, oceanic), MSA is exclusively produced by the above mechanism. Therefore it could act as useful tracer for biological activity in the remote marine environment such as the oceans surrounding the Antarctic continent. Both MSA (as methanesulfonate) and sulfuric acid (as sulfate), as proxy records of DMS, have been measured in ice cores from central Antarctica, and the relationship of these species to climate change has been identified (Legrand and Feniet-Saigne, 1991; Legrand and others, 1991).

Studies have demonstrated a reasonable correspondence of sulfate and MSA concentration in the atmosphere, and in fresh snow and in snow-pit samples (Jeffrezo and others, 1994), which gives confidence in interpreting depth profiles in terms of the sulfate and MSA content of the past atmosphere. To enhance our knowledge of the sulfur cycle and its global budget, and to evaluate unambiguously the past levels of biological activity in the oceans by means of deep ice-core analysis, it is crucially important to investigate the current spatial and temporal variation of sulfur species, particularly in the high-latitude regions which are sensitive to climate change and are expected to have large primary productivity (El Sayed and others, 1983). In this paper we present the MSA concentration data from an ice core from King George Island, which is near the northern end of the Antarctic Peninsula adjacent to the Weddell Sea, a region believed to have high marine phytoplankton production.

Our study was initiated to examine the seasonality of MSA deposition in the firn. Previous aerosol measurements at remote marine sites suggested a seasonal cycle with the peak concentration in summer and a low value in the cold season (Saltzman and others, 1986 (in low and mid-latitudes of the Pacific Ocean); Ayers and others, 1991 (Cape Grim, Tasmania); Prospero and others, 1991 (Mawson, Antarctica); Savoie and others, 1993 (Mawson, Palmer station and Marsh, Antarctica)). However, MSA might behave differently in ice cores. For instance, an ice core from Law Dome, East Antarctica, showed seasonal inconsistency of $\mathrm{MSA}, \delta^{18} \mathrm{O}$ and $\mathrm{nssSO}_{4}{ }^{2-}$ at a certain depth (Ivey and others, 1986). Mulvaney and others (1992), Minikin and others (1994) and Wagenbach and others (1994) have provided evidence of winter MSA peaks at greater depth in the cores from the central Antarctic Peninsula and Filchner-Ronne Ice Shelf. They assumed a mechanism of post-depositional migration and relocation of MSA, with the additional fact that the MSA maximum correlated with the summer snow for the top meters. In stark contrast, our first analysis of the upper $10 \mathrm{~m}$ of the King George Island ice cores showed apparent MSA peaks basically in the autumn. What is the driving force behind this unexpected seasonal phase differentiation? Could we interpret the atmospheric MSA pattern according to the core data? Along with a comparison against the $\mathrm{SO}_{4}{ }^{2-}$ and $\mathrm{nsSSO}_{4}{ }^{2-}$ profiles in firn, MSA variation vs depth will be 


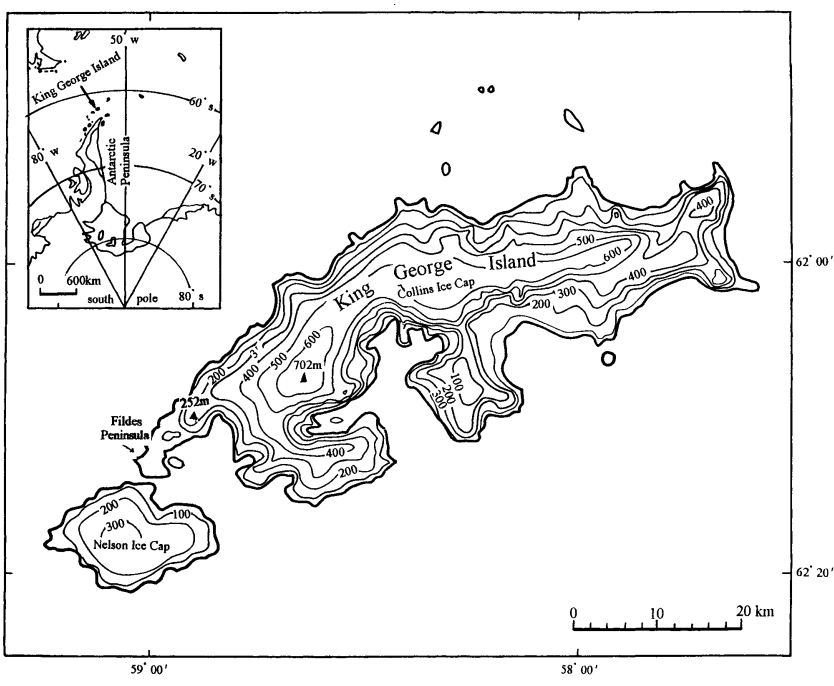

Fig. 1. Map of Collins Ice Cap, King George Island, showing location of drilling site.

investigated as a function of other influencing factors, such as the thermal regime of the glacier, the possible leaching effect of chemical species by existing liquid water, and the prevailing meteorological situation.

\section{SAMPLE COLLECTION AND ANALYSIS}

More than $90 \%$ of the area of King George Island is covered by a glacier, Collins Ice Cap. The ice core for this study was extracted on the summit (see Fig. 1) at $702 \mathrm{~m}$ a.s.l., as determined by a global positioning system survey by the Chinese Antarctic Research Expedition (CHINARE) in 1991. The accumulation rate at the drilling site is $4 \mathrm{~m}$ of snow, or $2480 \mathrm{~mm}$ w.e. (Wen and others, 1996). The mean annual air temperature there is estimated to be $-9.3^{\circ} \mathrm{C}$, as inferred by using a gradient of $-0.6^{\circ} \mathrm{C}$ per $100 \mathrm{~m}$ from a long meteorological data series at Marsh Base, King George Island. The measured $10 \mathrm{~m}$ temperature is about $-0.3^{\circ} \mathrm{C}$ (Han and others, 1995). Some ice layers were observed in the firn-pit stratigraphy, indicating summer melting on the glacier surface. The firn/ice transition depth is about $40 \mathrm{~m}$.

The snow/firn samples for this study were collected in December 1991. A $2.5 \mathrm{~m}$ deep snow pit was dug first at the drilling site. Great care was taken to prevent contamination: the pit was about $1 \mathrm{~km}$ from local activities, and the worker who did the sampling wore a full clean suit and disposable polyethylene gloves. After excavation of the snow pit, several additional centimeters were shaved from the pit wall just prior to collection of each sample, using clean polyethylene and stainless-steel tools. The polyethylene bags with samples were sealed in situ, packed in a box and stored in another snow pit, then kept at $<-20^{\circ} \mathrm{C}$ at the Chinese Great Wall station, King George Island.

The sample size for the snow pit is $20 \mathrm{~cm}$. Coring was conducted from the floor of the sampling snow pit with an electromechanical drill (Zhu and others, 1994). The generator for the power supply was placed $1 \mathrm{~km}$ downwind of the drilling site. The extracted cores, after logging by personnel wearing the same type of clothing as described above, were treated the same as the pit samples. They were transported to the U.S.A. in a cold storage container at $-20^{\circ} \mathrm{C}$ and kept in the laboratory, also in a frozen state, at the Climate Change Research Center, Institute for the Study of Earth,
Oceans and Space, University of New Hampshire, until subsampling and melting for analysis. Snow/firn cores were cut by band-saw to give at least 12 samples per annual accumulation layer. A piece of snow from the outside of each core section was removed for oxygen isotope determination, using gas source spectrometry. The surface of the other part was then removed, under a laminar-flow bench and using a knife pre-cleaned with $18 \mathrm{M} \Omega$ ultra-pure water to prevent contamination either by drilling or by the sectioning process. Samples were thawed prior to chemical analysis, which included major anion $\left(\mathrm{Cl}^{-}, \mathrm{NO}_{3}{ }^{-}, \mathrm{SO}_{4}{ }^{2-}\right)$ and cation $\left(\mathrm{Na}^{+}\right.$, $\left.\mathrm{K}^{+}, \mathrm{Ca}^{2+}, \mathrm{Mg}^{2+}\right)$ species, as well as $\mathrm{MSA}\left(\mathrm{CH}_{3} \mathrm{SO}_{3}{ }^{-}\right)$. The concentration of major ions was determined by a Dionex Model 2010 ion chromatograph, following published procedures (see Mayewski and others, 1986). MSA analyses were carried out using AGl1/AS1l columns, a hydroxide eluent and a gradient pump in a class-100 clean room. Samples were injected via a $200 \mu \mathrm{L}$ sample loop. The detection limit for MSA was $0.1 \mu \mathrm{g} \mathrm{kg}^{-1}\left(0.001 \mu \mathrm{eq} \mathrm{L}{ }^{-1}\right)$. Blanks were also analyzed, and MSA was undetectable. Analytical error is within $10 \%$ of the average concentration level.

\section{RESULTS}

The major chemical species in the King George Island core vary in a similar way with depth (Han and others, 1993). The $\mathrm{SO}_{4}{ }^{2-}$ concentration-depth profile, which is representative, is shown in Figure 2a. The fluctuation of $\mathrm{SO}_{4}{ }^{2-}$ concentration is large from one layer to another above $4 \mathrm{~m}$, suggesting limited post-depositional chemical mixing in the firn. It is the result of several factors, of which the most significant is probably the fairly large snow-accumulation rate of up to $4 \mathrm{~m}$ that prevents the deeper layers suffering from heavy percolation, limiting the migration of chemical species by liquid water. In fact, the snow in the top 3-4 $\mathrm{m}$ of the core is associated with deposition from the cold season after the 1991 summer (see right axis of Fig. 3 for dating). Limited gross percolation implies that the atmospheric signal linked with each accumulation event should be well preserved in individual layers. This is especially true for nearsurface layers, above $2 \mathrm{~m}$, which consist of newly deposited snow with little modification.

The concentration of methanesulfonate was determined to $11.5 \mathrm{~m}$ depth, but only the measurements above $10 \mathrm{~m}$ are used for the present analysis due to the systematic decrease in magnitude against depth for most cations and anions below $9 \mathrm{~m}$ (Han and others, 1993), which was attributed to a probable leaching effect in a relatively warmer environment (see Han and others, 1995, 1996). A total of 62 samples were taken for the methanesulfonate analysis, and 58 measurements were achieved. The arithmetic mean of 58 measurements is $0.17 \mu \mathrm{eq} \mathrm{L} \mathrm{L}^{-1}$ with a maximum of $0.73 \mu \mathrm{eq} \mathrm{L}^{-1}$ at $3.22 \mathrm{~m}$ depth and a minimum of $0.001 \mu \mathrm{eq} \mathrm{L}^{-1}$ at $6.43 \mathrm{~m}$ depth. The variation of MSA concentration vs depth is depicted in Figure 3. The most remarkable feature of the profile is the distinct peaks identified. Of three peaks above $9 \mathrm{~m}$, two are centered at 4 and $7.5 \mathrm{~m}$, and the third is at the very surface.

The oxygen isotope profile, matching the variation of MSA concentration, is also shown in Figure 3. Using this profile the snow deposition along the core was dated in association with the distribution of melt features in the stratigraphy. The top $9 \mathrm{~m}$ of the core consist of the mass deposited within about 2 years, from the austral summer of 1989/90 to that of 


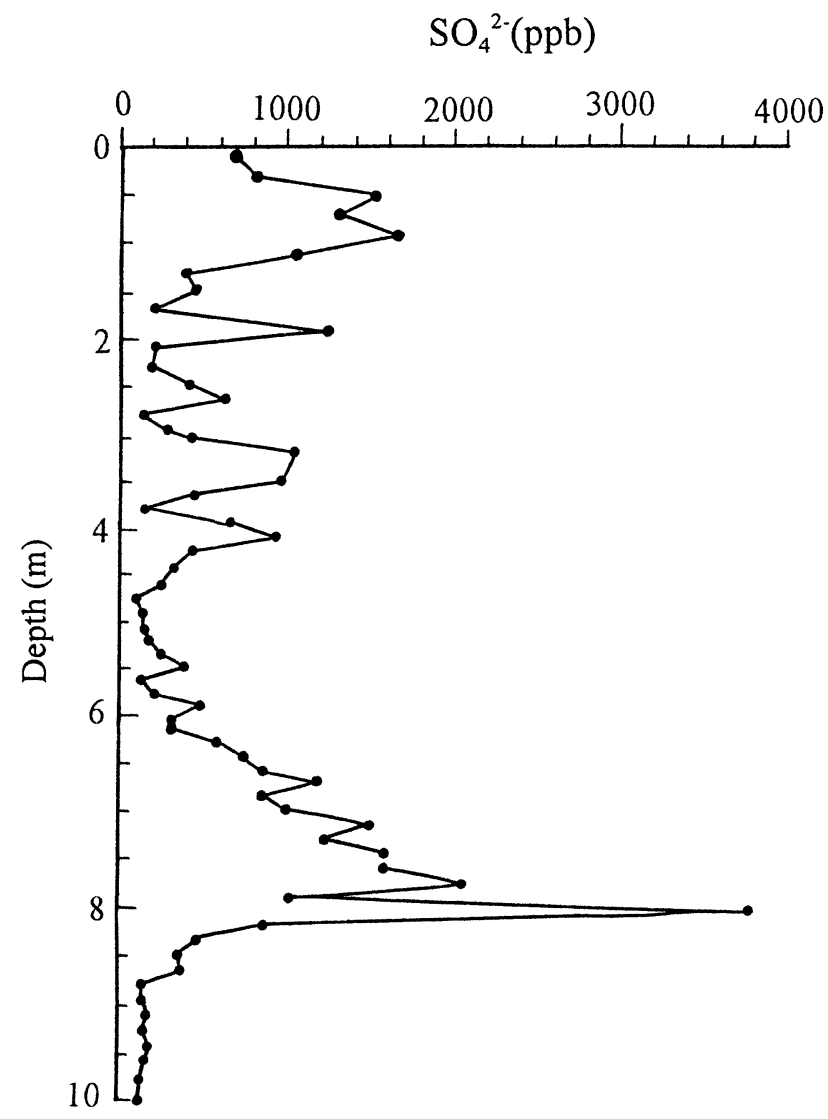

(a)

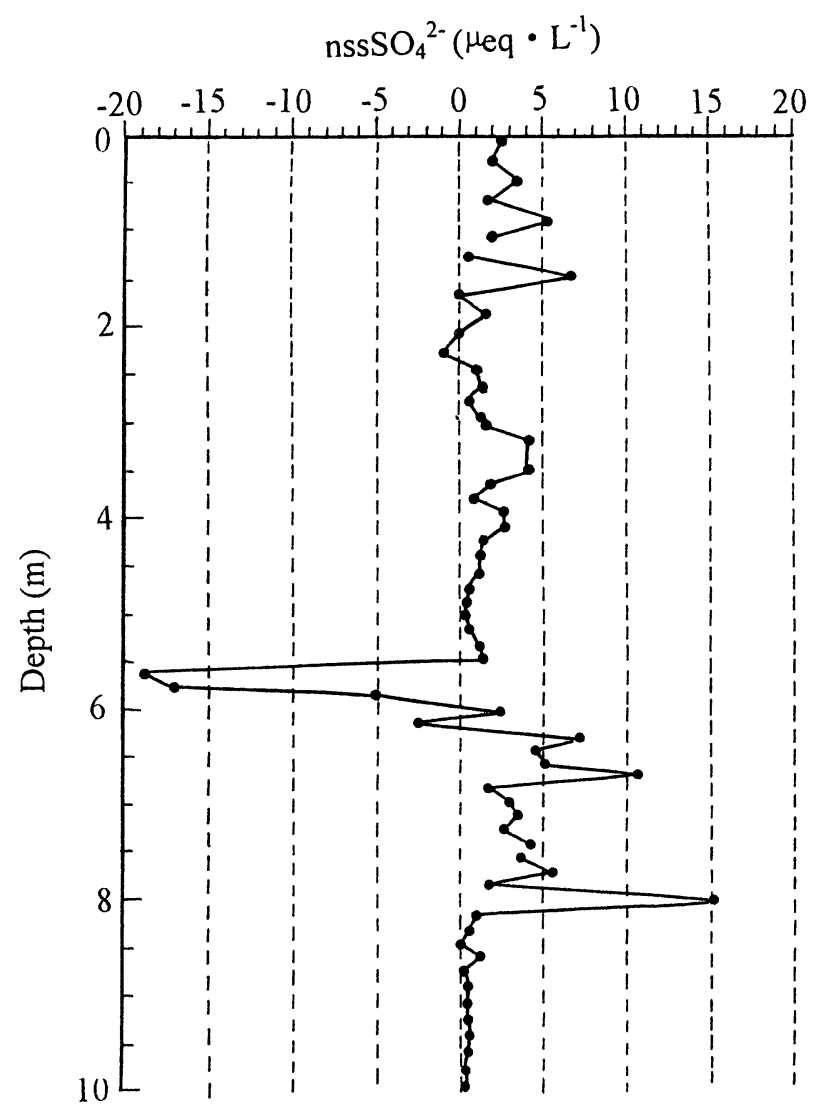

(b)

Fig. 2. Sulfate concentration variation of King George Island core vs depth: (a) depth profile of $\mathrm{SO}_{4}{ }^{2-}$ (in ppb); ( $b$ ) depth profile of $n s \mathrm{SO}_{4}^{2-}$ (in $\left.\mu e q L^{-1}\right)$.

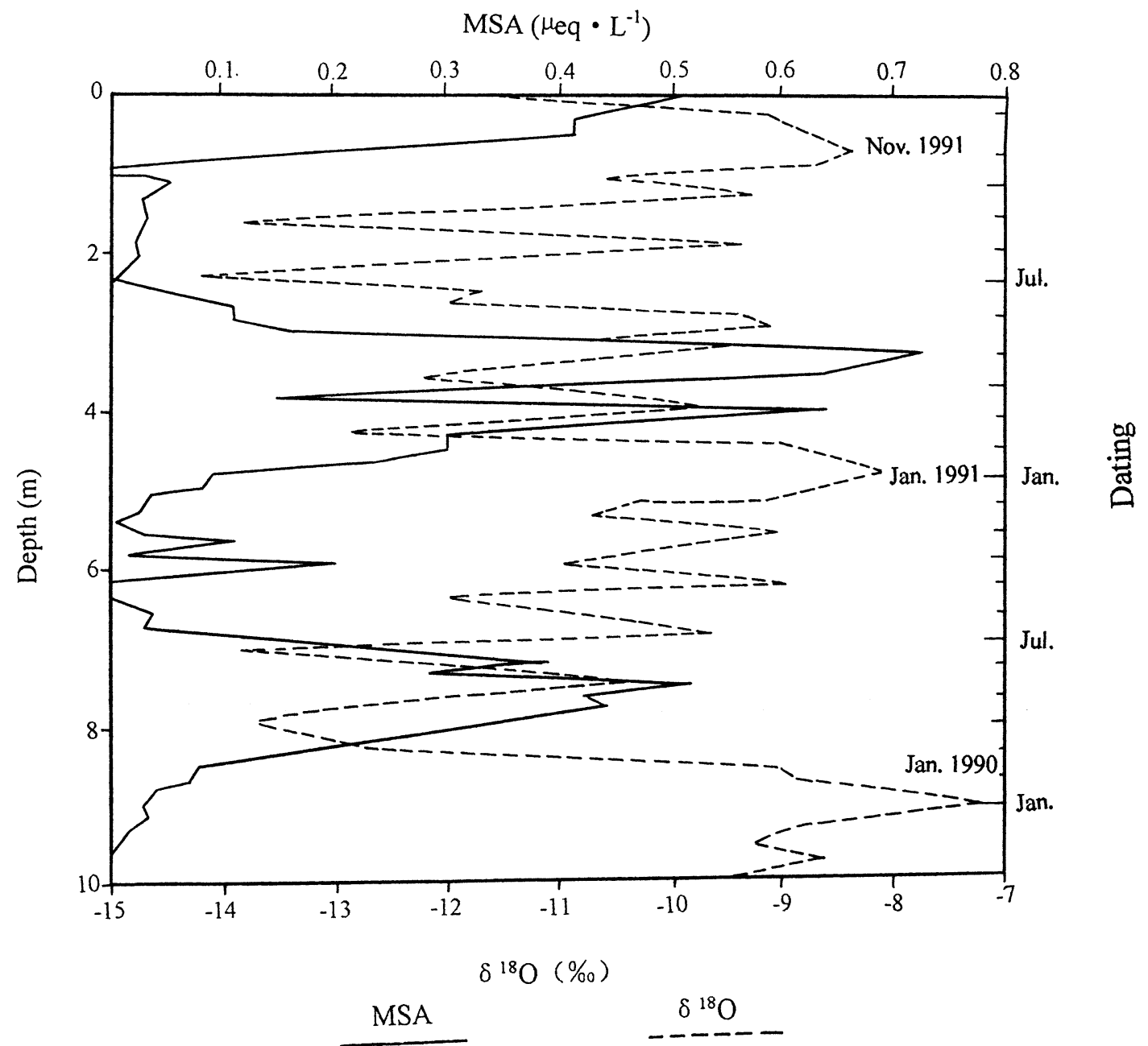

Fig. 3. MSA concentration (in $\mu e q L^{-1}$ ) in comparison with $\delta^{18} O$ variation vs depth for the King George Island core. 
1991/92. The newest peak in the $\delta^{18} \mathrm{O}$ profile is dated as November 1991 due to warm weather experienced 1 month before the drilling activity. As annual precipitation in King George Island shows even distribution through the year (Bian and others, 1993), and our over-year field observations suggested similar precipitation processes at the drilling site and at the lower elevations of the island, the snow/firn spans between adjacent maximum peaks can be divided into 12 equal parts (Fig. 3) when taking the maximum oxygen isotope ratio as indicative of the warmest month, January. Then the centers of two peaks at 4 and $7.5 \mathrm{~m}$ in the MSA profile belong within the snow deposited in autumn (about MarchMay). One may also judge from the broad episodes of higher MSA concentration that the peak starts to form in summer (about December), lasts for 5 months and ends in late autumn (May or June).

Non-sea-salt sulfate was calculated for each sample by subtraction of a "sea-salt" component from the observed sulfate concentration. The sea-salt component is usually estimated by assuming that sodium or magnesium originates from sea-salt aerosol and the molar ratio of 0.0603 for sulfate to sodium or 0.5305 for sulfate to magnesium (Millero, 1974) is maintained in the salt aerosol. However, owing to the dust fraction of sodium, an excess over the sea-water ratio of sodium to magnesium was noted in some samples. The dust fraction is additional to the marine fraction and is not solubilized during the melting step, but is solubilized during the elution of the sample in the ion chromatography, as pointed out for Antarctic snow by Legrand and Delmas (1987) and Legrand (1995). We have chosen the magnesium content to calculate excess sulfate by using the following expression:

$$
\left[\mathrm{SO}_{4}{ }^{2-}\right]_{\mathrm{nss}}=\left[\mathrm{SO}_{4}{ }^{2-}\right]_{\text {total }}-0.5305\left[\mathrm{Mg}^{2+}\right] \quad\left(\text { in } \mu \mathrm{eq} \mathrm{L}{ }^{-1}\right) \text {. }
$$

The use of magnesium ratio resulted in fewer negative nonsea-salt sulfate values, as shown in Figure 2b. The cause of the apparent depletion of sulfate relative to magnesium (or to sodium) in some sea-salt aerosol (Ivey and others, 1986; Minikin and others, 1994) is still unclear, but it has been argued that this chemical fractionation could occur because of the low-atmosphere temperatures (Gjessing, 1989). The remaining negative non-sea-salt sulfate results are similar to the cumulative analytical uncertainty $(<10 \%$ of the total sulfate concentration). The $\mathrm{nssSO}_{4}{ }^{2-}$ is equivalent to about $15 \%$ of the total sulfate in this core, indicating that the marine biogenic component is an important part of the sulfur budget, although a contribution from volcanic or anthropogenic sources is possible for this subantarctic island where several stations are located. However, this level is likely to be small compared to the biogenic contribution.

A higher positive correlation between MSA and $\mathrm{nsSSO}_{4}{ }^{2-}$ was given by our linear regression $(r=0.70)$, and the ratio of MSA to $\mathrm{nsSSO}_{4}{ }^{2-}$ (in $\mu \mathrm{eq} \mathrm{L}^{-1}$ ) could be deduced directly from the slope of the regression equation. Thus we have

$$
\mathrm{MSA} / \mathrm{nssSO}_{4}{ }^{2-}=0.20 \text {. }
$$

The stable trend in $\mathrm{MSA} / \mathrm{nssSO}_{4}{ }^{2-}$ ratio rather than MSA itself implies that the dominant source region of MSA has not changed substantially in the sampled 2 years. The MSA/ $\mathrm{nssSO}_{4}{ }^{2-}$ ratio in King George Island firn is very close to that reported for the firn/ice from sites surrounding the Weddell Sea (see Table 1).
Table 1. Mean MSA and nss $\mathrm{SO}_{4}{ }^{2-}$ in firn/ice cores surrounding

\begin{tabular}{|c|c|c|c|c|}
\hline Site & $\begin{array}{r}M S A \\
\mu \text { eq } \mathrm{L}^{-}\end{array}$ & $\begin{array}{l}\mathrm{nss-}^{-} \\
\mathrm{SO}_{4}{ }^{2-} \\
\mu \mathrm{eq} \mathrm{L} \mathrm{L}^{-1}\end{array}$ & $\begin{array}{c}\mathrm{MSA} / \\
\mathrm{nsSOO}_{4}{ }^{2-}\end{array}$ & Source \\
\hline King George Island & 0.17 & 0.85 & 0.20 & This paper \\
\hline Dolleman Island & 0.85 & 3.72 & 0.23 & Mulvaney and others (1992) \\
\hline Gomez Nunataks & 0.11 & 0.60 & 0.18 & Mulvaney and others (1992) \\
\hline Dyer Plateau & 0.09 & 0.56 & 0.16 & Mulvaney and others (1992) \\
\hline $\begin{array}{l}\text { Berkner Island } \\
\text { north } \\
\text { south }\end{array}$ & $\begin{array}{l}0.20 \\
0.17\end{array}$ & $\begin{array}{l}1.17 \\
0.88\end{array}$ & $\begin{array}{l}0.17 \\
0.20\end{array}$ & $\begin{array}{l}\text { Wagenbach and others (1994) } \\
\text { Wagenbach and others (1994) }\end{array}$ \\
\hline \multicolumn{5}{|c|}{ Filchner-Ronne Ice Shelf } \\
\hline north & 0.20 & 1.00 & 0.20 & Minikin and others (1994) \\
\hline south & 0.12 & 0.82 & 0.15 & Minikin and others (1994) \\
\hline
\end{tabular}
the Weddell Sea

\section{DISGUSSION AND GONGLUSION}

The driving forces behind the seasonal pattern of MSA concentration both in the remote marine atmosphere and in snow/ice of polar regions have been extensively discussed. As to the higher MSA content during warm months and the greatest seasonal changes at higher latitudes over the Pacific Ocean, Saltzman and others (1986) pointed out that at higher latitudes, winter conditions produce slower oxidation rates of DMS to MSA because of reduced temperature, light levels and production of photochemical oxidants. The reaction pathway may also be affected: non-photochemical reaction pathways, perhaps involving $\mathrm{NO}_{3}$ radicals, could play a more important role in winter. Both of these effects are in phase, resulting in the lower concentration of MSA in colder months, or higher concentration in warmer months. Such a "common" seasonality of MSA is supported by a number of other studies. For example, the aerosol sampling at Mawson, East Antarctica, and at Palmer station, Antarctic Peninsula, exhibited a large seasonal variation, with MSA concentrations one order of magnitude higher during austral summer than during winter (Savoie and others, 1993). The ice cores from Dolleman Island (Mulvaney and others, 1992) and from central Filchner-Ronne Ice Shelf (Minikin and others, 1994) showed pronounced annual cycles, with maxima in the summer firn for the top few meters. Mulvaney and others (1992) argued that temperatures typical of the Antarctic Peninsula are favorable for the oxidation of DMS to MSA due to the preferential addition-branching of a hydrogen atom in the reaction of DMS with $\mathrm{OH}$ radical. Pasteur and others (1995) stressed the correlation of MSA to sea-ice extent in that area. That may explain why the Weddell Sea becomes a distinctive region with higher biogenic sulfur production. Nevertheless, those mechanisms acting in the Antarctic Peninsula region might also be effective for the whole of offshore Antarctica, where up to $10 \%$ of the total global flux of DMS to the atmosphere emanates from the sea (Gibson and others, 1989). It probably also applies in other seasons, if the occasional combination of conditions is positive. Field observations provide supporting evidence. For instance, from 7 to 14 April 1986, during the austral autumn, a "surprising" high mean MSA concentration in the atmosphere aerosols, up to $0.27 \mathrm{n} \mathrm{mol} \mathrm{m}^{-3}$, was observed over Gerlache Strait, close to our studied region (Berresheim, 1987). The 1989 Byrd Station core (NBY89) also showed clear seasonal cycles with summer/ 
fall maxima (Langway and others, 1994). Our data may also suggest higher MSA levels during summer/autumn in the atmosphere of King George Island.

Several factors may account for the incorrect dating of firn/ice cores. In the case of King George Island, where the snow-accumulation rate is as high as $4 \mathrm{~m}$, the practical sampling frequency of $>12$ samples in a year should identify the most important snowfall events in the core. However, dividing the annual snow deposition into 12 equal parts, as in the present study, could introduce errors into the subannual resolution, as the hypothesis of homogeneous precipitation during a year may differ somewhat from the real snowaccumulation process. Also we could not see distinct winter minima in the oxygen isotope ratio profile, removing another check on the sub-annual dating.

Post-depositional elution of chemical species could occur when liquid water exists in the firn. Collins Ice Cap is a relatively warm glacier, and surface melting must take place in summer, as evidenced by the ice layers in the stratigraphy, but the situation might be different in other seasons. To make this clear, the two $\mathrm{SO}_{4}{ }^{2-}$ profiles in Figure 2 and the MSA profile in Figure 3 are further investigated. Assuming that the original signal has not changed for the snow above $2 \mathrm{~m}$, which we take to be the mass deposited in the cold season according to the dating, then we observe a good synchronization between MSA and $\mathrm{SO}_{4}{ }^{2-}$ concentration. But at 3-4 m depth, where the second MSA peak is located, MSA and $\mathrm{SO}_{4}{ }^{2-}$ are less well synchronized. A similar pattern can be identified at about $8 \mathrm{~m}$ depth where the largest peaks of MSA and $\mathrm{SO}_{4}{ }^{2-}$, as well as of $\mathrm{nsSSO}_{4}{ }^{2-}$, are located. Between these two depths there is a trough, with a smooth curve for both $\mathrm{SO}_{4}{ }^{2-}$ profiles, dated to January 1991. Below $9 \mathrm{~m}$, all three profiles are characterized by heavy leaching, with values for $\mathrm{SO}_{4}{ }^{2-}, \mathrm{nssSO}_{4}{ }^{2-}$ and MSA all falling, while $\delta^{18} \mathrm{O}$ is close to the mean value. The described variation for the three soluble species implies elution of ions below $2 \mathrm{~m}$. The low values of both $\mathrm{SO}_{4}{ }^{2-}$ profiles at around $5 \mathrm{~m}$ depth are the direct effect of ion leaching in the summer when the mass was at the surface, while the peaks of both MSA and $\mathrm{SO}_{4}{ }^{2-}$ profiles at about $8 \mathrm{~m}$ are probably the result of relocation of removed ions from horizons above. Nevertheless, the possibility of seasonal higher contents in the atmosphere cannot be completely rejected as one of the MSA contributors. Because the total $\mathrm{SO}_{4}{ }^{2-}$ profile is linked in part to the input of sea water, the coincidence of the MSA peak at $8 \mathrm{~m}$ may imply the combination of MSA with some cations. The second MSA profile peak, at 3-4 m, might therefore be formed under similar conditions, even though it is impossible for summer melt to percolate into it, as the material above is all deposited in the cold season. It is likely that a certain amount of water still exists within the snowpack after the end of summer. As MSA is more soluble in water and more easily moved than other ions (Mulvaney and others, 1992), it is leached and migrated preferentially downwards. The mechanism underlying the relocation of MSA in the King George Island core might be the same as assumed by Mulvaney and others (1992): the relatively higher freezing temperature of newly formed MSA salts, such as $\mathrm{Na}^{+}$ or $\mathrm{Mg}^{2+}$, allows the "freezing" to take place. It can be inferred that the MSA migration hypothesis proposed for the deep part of some Antarctic Peninsula cores holds true also for the firn of Collins Ice Cap even though there is no interlinked network of veins within the firn as the removing channel of MSA ions. It seems, therefore, the chief prerequisite for MSA migration is not the form of space allowing the liquid to move, but rather the existence and perhaps the amount of water in liquid phase.

The identification of MSA migration in the King George Island core negates direct interpretation of the snow MSA concentration in terms of the atmospheric seasonality except for the very surface part, and the extreme values are no longer the record of chemical species in the air. Consequently, the basis for the annual flux calculation is changed because the migration of MSA could reach a depth beyond an annual layer in which it was laid down. The $\mathrm{MSA} / \mathrm{nssSO}_{4}{ }^{2-}$ ratio, as a regional index adopted by other researchers, should be calculated as follows instead of being determined by linear regression:

$$
\mathrm{MSA} / \mathrm{nssSO}_{4}{ }^{2-}=\sum[\mathrm{MSA}]_{i} / \sum\left[\mathrm{nssSO}_{4}{ }^{2-}\right]_{i},
$$

where $[\mathrm{MSA}]_{i}$ and $\sum\left[\mathrm{nssSO}_{4}{ }^{2-}\right]_{i}$ are the $\mathrm{MSA}$ and $\mathrm{nssSO}_{4}{ }^{2-}$ concentration (in $\mu \mathrm{eq} \mathrm{L}^{-1}$ ) for the $i$ th value. The resultant ratio from Equation (3) for the King George Island core is $0.22,10 \%$ higher than that obtained via linear regression. However, it is closer to that from the Dolleman Island core (Table 1).

In summary, the analysis of MSA and corresponding $\mathrm{SO}_{4}{ }^{2-}$ and $\mathrm{nsSSO}_{4}{ }^{2-}$ profiles obtained from the King George Island ice core suggests that two of the three peaks in the MSA profile may largely result from migration and relocation of MSA. The examination of MSA migration in the surface firn suggests a mechanism similar to that observed in the deep part of some other Antarctic glaciers, supporting the migration hypothesis proposed by prior researchers, and extending it to a near-temperate glacier.

The general pattern of MSA seasonality in the atmosphere of King George Island could only be derived from the near-surface part of the profile. MSA concentrations were highest in summer and lowest in winter, but this does not exclude the possibility that the high concentration extends into the autumn. Because of post-depositional modification, the MSA extremes for the firn no longer signify the levels in the atmosphere, and the basis for annual flux and for the regional index calculation is changed. The $\mathrm{MSA} / \mathrm{nsSSO}_{4}{ }^{2-}$ ratio for King George Island obtained by a newly introduced computation is $0.22,10 \%$ higher than when the effect of MSA migration is ignored.

\section{ACKNOWLEDGEMENTS}

The present research was partly supported by Chinese National Science Foundation grant No. 48970020. The firn/ ice core was obtained during summer 1991/92 by CHINARE. The authors appreciate the logistic support provided by Fan Runqing, officer in charger of Chinese Great Wall station, and all the summer members. We wish to thank Zhu Guocai, Gao Xinsheng, Jing Xiaoping, Kang Jiancheng and Wen Jiahong, as well as several Uruguayan scientists who put great effort into the drilling operation. Valuable analysis of MSA and $\mathrm{SO}_{4}{ }^{2-}$ was provided by $\mathrm{S}$. Whitlow in the Climate Change Research Center, University of New Hampshire.

\section{REFERENGES}

Ayers, G. P., J. P. Ivey and R.W. Gillet. 1991. Coherence between seasonal cycles of dimethyl sulphide, methanesulphonate and sulphate in marine air. Nature, 349(6308), 404-406.

Berresheim, H. 1987. Biogenic sulfur emissions from the subantarctic and Antarctic oceans. 7. Geophys. Res., 92(D11), 13,245-13,262.

Bian Lingen, Xue Zhengfu, Lu Longhua, Lu Changgui, Jia Pengqun and 
Zhang Yongping. 1993. CHINARE Data Report 6. Beijing, Polar Research Institute of China. (Meteorology 5.)

Charlson, R. J., J. E. Lovelock, M. O. Andreae and S. G. Warren. 1987. Oceanic phytoplankton, atmospheric sulphur, cloud albedo and climate. Nature, 326(6114), 655-661.

El Sayed, S. Z., D. C. Bigg and O. Holm-Hansen. 1983. Phytoplankton standing crop, primary productivity and near-surface nitrogeneous nutrient fields in the Ross Sea, Antarctica. Deep-Sea Res., 80, 871-886.

Gibson, J. A. E., R. C. Garrick, H. R. Burton and A. R. McTaggart. 1989 Dimethylsulphide and the alga Phaeocystis pouchetii in Antarctic coastal waters. Mar. Biol., 104(2), 339-346.

Gjessing, Y.T. 1989. Excess and deficit of sulfate in polar snow. Atmos. Environ., 18(1), 825-830.

Han Jiankang, Kang Jiancheng, Wen Jiahong, P. A. Mayewski and M. S. Twickler. 1993. [Concentration characteristics of soluble impurities in the surface snow of Collins Ice Cap, King George Island, Antarctica.] Antart. Res. (Chinese), 5(2), 28-33. [In Chinese with English summary.]

Han Jiankang, Jin Huijun, Wen Jiahong and Shang Xinchun. 1995. Temperature distribution of Collins Ice Cap, King George Island, Antarctica. Antarct. Res., 6(2), 57-65.

Han Jiankang, K. Goto-Azuma, M. Nakawo, Kang Jiancheng and Xie Zichu. 1996. [Studies on the mechanism and effect of eluviation of snowpack.] In Cheng Guodong, ed. Fifth Chinese Conference on Glaciology and Geocryology, 18-22 August 1996, Lanzhou, China. Proceedings. Vol. 2. Lanzhou, Gansu Culture Press, 996-1007. [In Chinese with English abstract.]

Ivey, J. P., D. M. Davies, V. Morgan and G. P. Ayers. 1986. Methanesulphonate in Antarctic ice. Tellus, 38B(5), 375-379.

Jaffrezo, J.-L., C. I. Davidson, M. Legrand andJ. E. Dibb. 1994. Sulfate and MSA in the air and snow on the Greenland ice sheet. F. Geophys. Res., 99(D), $1241-1253$.

Langway, C. C., Jr, K. Osada, H. B. Clausen, C. U. Hammer, H. Shoji and A. Mitani. 1994. New chemical stratigraphy over the last millennium for Byrd Station, Antarctica. Tellus, 46B (1), 40-51.

Legrand, M. 1995. Sulphur-derived species in polar ice: a review. In Delmas, R. J., ed. Ice core studies of global biogeochemical cycles. Berlin, etc., SpringerVerlag, 91-119. (NATO ASI Series I: Global Environmental Change 30.)

Legrand, M. R. and R. J. Delmas. 1987. A 220-year continuous record of volcanic $\mathrm{H}_{2} \mathrm{SO}_{4}$ in the Antarctic ice sheet. Nature, 327(6124), 671-676.

Legrand, M. and C. Feniet-Saigne. 1991. Methanesulfonic acid in south polar snow layers: a record of strong El Niño? Geophys. Res. Lett., 18(2), 187-190.

Legrand, M., C. Feniet-Saigne, E. S. Saltzman, C. Germain, N. I. Barkov and V. N. Petrov. 1991. Ice-core record of oceanic emissions of dimethylsulphide during the last climate cycle. Nature, 350(6314), 144-146.

Mayewski, P. A. and 7 others. 1986. Sulfate and nitrate concentrations from a south Greenland ice core. Science, 232(4753), 975-977.

Millero, F. J. 1974. The physical chemistry of seawater. Annu. Rev. Earth Planet. Sci., 2, 101-150.

Minikin, A., D. Wagenbach, W. Graf andJ. Kipfstuhl. 1994. Spatial and seasonal variations of the snow chemistry at the central Filchner-Ronne Ice Shelf, Antarctica. Ann. Glaciol., 20, 283-290.

Mulvaney, R., E. C. Pasteur, D. A. Peel, E. S. Saltzman and P.-Y. Whung. 1992. The ratio of MSA to non-sea-salt sulphate in Antarctic Peninsula ice cores. Tellus, 44B (4), 295-303.

Pasteur, E. G., R. Mulvaney, D. A. Peel, E. S. Saltzman and P.-Y. Whung. 1995. A 340 year record of biogenic sulphur from the Weddell Sea area, Antarctica. Ann. Glaciol., 21, 169-174.

Prospero, J. M., D. L. Savoie, E. S. Saltzman and R. Larson. 1991. Impact of oceanic sources of biogenic sulphur on sulphate aerosol concentrations at Mawson, Antarctica. Nature, 350(6315), 221-223.

Saltzman, E. S., D. L. Savoie, J. M. Prospero and R. G. Zika. 1986. Methanesulphonic acid and non-sea-salt sulphate in Pacific air: regional and seasonal variations. 7. Atmos. Chem., 4, 227-240.

Savoie, D. L. and 8 others. 1993. Nitrogen and sulphur species in Antarctic aerosols at Mawson, Palmer Station and Marsh (King George Island). 7. Atmos. Chem., $17(2), 95-122$.

Wagenbach, D. and 6 others. 1994. Reconnaissance of chemical and isotopic firn properties on top of Berkner Island, Antarctica. Ann. Glaciol., 20, 307-312.

Wen Jiahong and 6 others. 1996. [The preliminary study of the stratigraphy and mass balance of the cores from Collins Ice Cap, Antarctica.] In Zhou Xiuji and Lu Longhua, eds. The study of the relationship between Antarctica and the global climate and environment. Beijing, Meteorology Press, 210-215. [In Chinese.]

Zhu Guocai and Han Jiankang. 1994. BZXJ super light ice core drill. Natl. Inst. Polar Res. Mem., Special Issue 49, 87-92. 